\title{
The AHP-Based Assessment of Public Services With Respect to Different Groups of Customers of Polish Local Government*
}

\author{
Anna Prusak \\ Krakow University of Economics, Krakow, Poland \\ Jacek Strojny \\ Rzeszow University of Technology, Rzeszow, Poland \\ Piotr Stefanów \\ A. F. Modrzewski Krakow University, Krakow, Poland \\ Katarzyna Machaj \\ District Office of Nowy Targ, Nowy Targ, Poland
}

\begin{abstract}
The situation of the contemporary economic systems is based on their ability to ensure optimal response to the customer needs. There are several important groups of clients, who may determine development processes and who are recipients of public services. They include: residents, entrepreneurs, tourists, and State Treasury. Local governments are equipped with a range of legal instruments to provide public services addressed to the selected clients. The objective of this paper is to present the application of the AHP method to assess the significance of the selected categories of public services for different groups of clients in Poland. The results allow setting priorities for future policy and adjust the tasks to the specific expectations of each group of clients. The model of assessment of public services was built using the analytic hierarchy process (AHP). Since the 1970's, this multicriteria decision-support method has been used by researchers and practitioners in many areas of socioeconomic life. The case study presented in this paper involved 14 experts - public administration workers in one of the districts in Southern Poland. The survey consisted of two stages. First, they assessed — using the AHP — the influence of each group of customers on local development processes. The most important was "business" (priority 38.7\%), followed by "tourists" (29.7\%), "citizens" (26.1\%), and "central administration" (5.5\%). Second, they evaluated at the five-point Likert scale the influence of over 20 different public services with respect to different groups of clients. The results were aggregated using arithmetic mean and multiplied by the priorities of the clients. The synthesized final score indicated the most significant public activities overall, which were "roads" (4.16), "transport" (3.93), and "tourism" (3.84).
\end{abstract}

Keywords: public services, local government, analytic hierarchy process (AHP) analysis, public administration, customer analysis

\footnotetext{
* Acknowledgments: The research presented in this paper was funded from the Grant of the National Science Center based on decision No. DEC-2011/01/D/HS4/04006. The authors thank the team of the District Office in Nowy Targ for their participation in this study. We are particularly grateful to the project manager of the Strategy Preparation Project.

Anna Prusak, Ph.D., Krakow University of Economics, Krakow, Poland.

Jacek Strojny, Ph.D., Rzeszow University of Technology, Krakow, Poland.

Piotr Stefanów, Ph.D., A. F. Modrzewski Krakow University, Krakow, Poland.

Katarzyna Machaj, master degree, District Office of Nowy Targ, Nowy Targ, Poland.

Correspondence concerning this article should be addressed to Jacek Strojny, Department of Economics, Rzeszow University of Technology, Av. Powstańców Warszawy 12, 35-959 Rzeszów, Poland.
} 


\section{Introduction}

The issue of assessment of public services is a part of the concept of good governance. This is a holistic theory, which describes the way of acting of public institutions in current, global, and complex environment (Weiss, 2000; Graham, Amos, \& Plumptre, 2003). Currently, it is very popular to look at this kind of organizations from the market point of view (Buchacz \& Wysocki, 2002; Kelly, 2005). One of the most important aspects of this approach is to assure high quality of public services, and of all processes in public administration. This subject attracted a great deal of attention from scientists and practitioners. Since the turn of the 21 st century, the increasing number of investigations focused on the construction of general satisfaction indexes of the customers of public institutions has been observed in many countries, especially in Europe and North America (Fornell, Johnson, Anderson, \& Cha Jeasung, 1996; Schmidt \& Strickland, 1998; Moore, Clarke, Johnson, Seargeant, \& Steele, 1998; Bouckaert, 1995; Charbonneau \& Van Ryzin, 2012). Importantly, it is not only about the customer satisfaction, but also about the effectiveness and efficiency of processes of producing and delivering public services (Boex, 2012; Rhys \& Van de Walle, 2013; Kersting \& Vetter, 2013). These two dimensions constitute the basis for the holistic quality management. Such point of view should be taken in both operational and strategic process management. The process of improvement of the quality of public services should be based on their optimization from the perspective of different groups of customers. Therefore, it is essential to identify which of the public services is the key for citizens, companies, tourists, etc. It allows their realization in a way ensuring high customer satisfaction and appropriate level of financing. Institutions of local government in Poland have the capacity to reallocate some part of own revenues to those public services, which are the most important for the customers. In order to identify them, it is useful to prepare the rank of public services, with the use of, i.e., preference analysis and multiple criteria decision analysis (MCDA) methods.

The objective of the present research is to apply the analytic hierarchy process (AHP) method of assessment of the selected categories of public services with respect to different groups of clients-recipients of these services. Specifically, the paper discusses which public services provided by local government should be considered a priority, taking into account the importance of different customers and their satisfaction thereof. Subsequently, the following research questions have been formulated:

(1) What is the significance of the customers of public administration (recipients of public services) with respect to the district development processes?

(2) How powerful are public services to influence different groups of clients and their satisfaction (which, in turn, may influence their future financial decisions)?

(3) Which public services are the most influential and important for socioeconomic policy of the district, and therefore should be considered a priority in defining future development processes?

The above problems are clearly multidimensional and require consideration of various aspects. Thus, these research questions need engagement of proper decision-making methods. One of such methods is the AHP, the most widely used multicriteria decision-support tool allowing to solve a variety of problems (Saaty \& Forman, 1992). It was created in 1970's by American professor Saaty, and since then it has gained an increasing attention of researchers and practitioners. It has been applied worldwide by different organizations, including private companies and public authorities (Saaty, 2008). It first decomposes a complex problem into a hierarchy consisting of goal, criteria, and decision alternatives. Then, judgments reflecting the relative importance 
(preference) of these elements are collected from the relevant experts. Finally, weights (priorities) are calculated and the highest value indicates the optimal solution.

The AHP-based assessment presented in this paper has been implemented in the District Office of Nowy Targ, located in Malopolska region (Southern Poland). This place has been selected due to the innovative approach to strategic and operational management reflected in specifications taken by local authorities, such as task-budgeting, project management, valuation of products served, and bonus system (such actions are usual in the private sector but not often in Polish public administration). In 2014, another project was launched aiming to develop a new strategic plan based on client orientation, project orientation, and benchmarking. One of the most important goals of this project was to identify the instruments of influence on the main groups of clients and subsequently to improve the competitive position of the whole district. ${ }^{1}$

The paper not only demonstrates the application of the AHP in public administration, but also reports a real-life decision-making process. As such, it constitutes an interesting case study with implications for researchers and practitioners in modern public administration.

\section{Key Aspects of Management of Public Services in Polish Local Government}

One of the major challenges of Polish democracy after a transition period in 1989/1990 was introduction of the mechanism of local and regional governance. Local government reform (municipality level) was the main priority for the first post-communist government in September 1989 in Poland. It introduced elected local government only at the level of municipality (Municipal Government Act, 1990). The upper tiers of territorial divisions were managed by state administration. It functioned till 1998, when the new upper tiers of local government were introduced. At present, there are three tiers of territorial governments: 16 regions, 315 districts, and more than 2,500 municipalities. At municipal and district level, local government is the only form of public administration, while regional tier has a dual structure, including elected regional government and a governor nominated by the Prime Minister with his own administrative apparatus (Bury \& Swianiewicz, 2008). The administrative reform of January 1999 was the next step in building the public administration structure with the engagement of regional and local communities. The legal conditions and related financial mechanisms create the possibility of the real influence of local authorities on different aspects of local and regional development processes. Each tier of local government has particular tasks to fulfill for local community and for other entities (i.e., State Treasury). Statutory tasks of the local government in Poland are specified in: Municipal Government Act, District Government Act, and Regional Government Act (Parliament, 1990; 1998a; 1998b). As most of these tasks are mandatory, the governments cannot simply select the most needed ones.

However, local authorities may influence the efficiency of their performance and improve the quality of spending public money. There are also tasks, which are not obligatory, but stem from the adopted strategy. Thus, the catalogue of public services can be in fact broader and should be further extended in response to the current needs, budget, and competencies. The term public service can be defined as a task, which aims to produce certain public goods. They are addressed to the society and financed by public money (Sołtys, 2013). Delivering them to the society should be based on a thorough analysis of the customer needs. Such analysis should start from studying these tasks and their effects and should be used as a tool to create the competitive

${ }^{1}$ The implementation of AHP was a part of this project and was provided by authors of this paper. 
advantage of a territorial unit. High quality of public services constitutes a decent foundation for improving relations with stakeholders and making country/region/district/municipality more attractive for them (Osborne, Radnor, \& Nasi, 2013). Consequently, they can choose this territorial unit for living, investing, or visiting. One must remember that stakeholders are genuinely interested in public administration activity (Soma \& Vatn, 2014). The most important group of stakeholders is clients, who are direct users (recipients) of public services. Contemporary institutions are advised to identify different groups of clients, recognize and analyze their specific needs, and optimize public services to win on the very competitive markets of mobile resources (intellectual capital market and investment market) or tourists (Bobińska, 2012).

In order to intensify development processes, it is necessary to optimize performance of public services for a particular group of clients. Different levels of local government involve various types of clients. Institutions of public administration of the region, district, and municipality have the specific scope of the services provided. In further analysis, it should be taken into consideration that there are two types of relations between public institutions and their customers, specifically:

- demand-driven, market based relations, in which the customer can assess the quality of public services provided by regional or local government and respond to it, for example, a company looking to invest perceives his relationship with the local authority as a criterion determining his investment decisions;

- forced by regulations, included in legal directory, such as the relationship between central administration and local authority. In Poland, local and regional governments provide certain public services for central administration, e.g., by managing the real estate of state, treasury, public safety, national defense, education, and public health.

\section{Methodology-Basic Information About the AHP and Its Application in Decision-Making}

The AHP decomposes a complex multifaceted problem into a hierarchical structure consisting of the goal (at the top of the hierarchy) and criteria and decision variants (alternatives, at the bottom of the hierarchy). In most cases, criteria are divided into sub-criteria. Such a four-level hierarchical model presented in Figure 1 is used to structure a majority of decision-making problems.

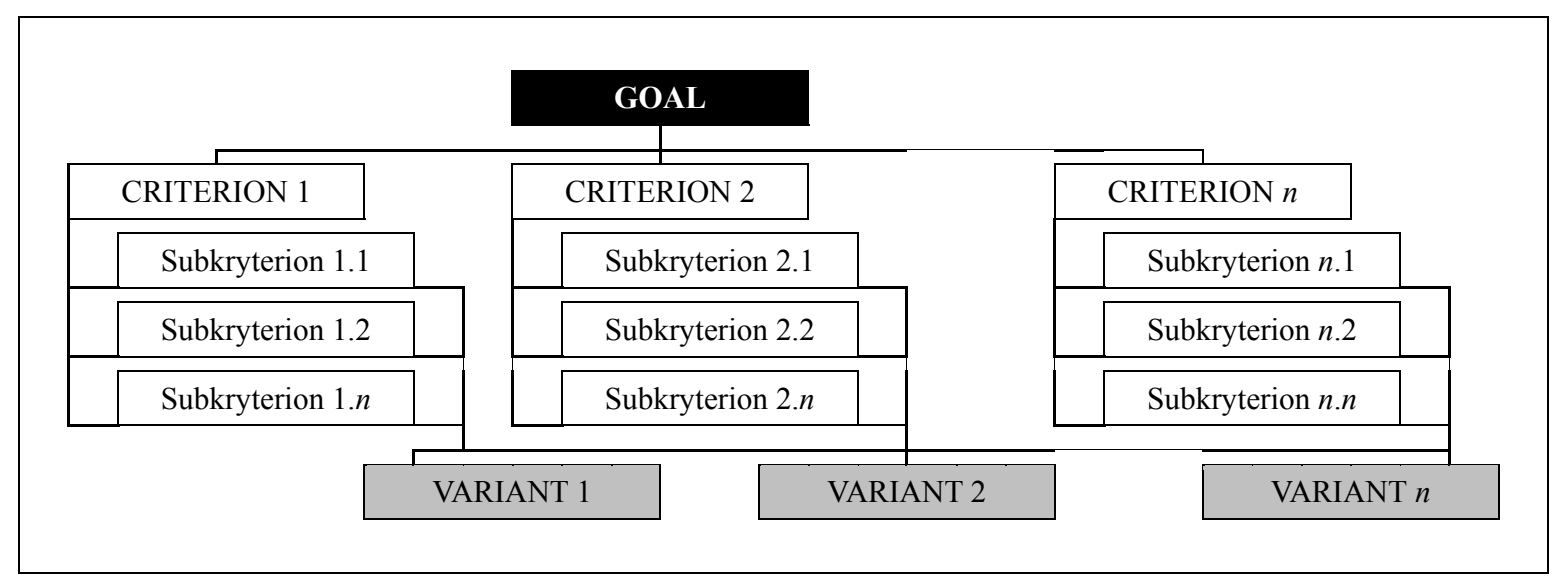

Figure 1. The four-level AHP hierarchical model.

Some problems require more sophisticated hierarchies, consisting of other elements, such as stakeholders, their objectives, environment, and many others (Saaty \& Forman, 1992). Once the hierarchical model has been 
structured, decision makers or experts make pairwise comparisons for each level of the model, using the bipolar nine-point fundamental scale, from "1" indicating the same importance (preference, likelihood) of two elements A and B, to "9" which corresponds to the extreme dominance of A over B (or B over A, respectively) (Figure 2).

\begin{tabular}{|c|c|c|c|c|c|c|c|c|c|c|}
\hline & 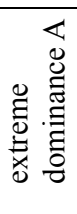 & 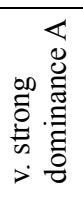 & 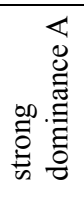 & 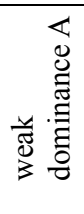 & 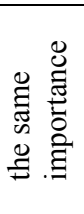 & 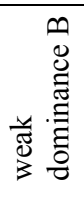 & 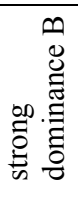 & 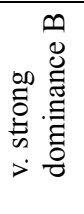 & 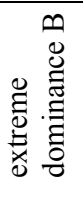 & B \\
\hline $\mathbf{A}$ & 1 & 2 & 3 & 4 & 5 & 6 & 7 & 8 & 9 & \\
\hline
\end{tabular}

Figure 2. The nine-point pairwise comparison scale.

Pairwise comparison is the process of comparing the relative importance, preference, or likelihood of two elements ("children") with respect to an element at the level above (parent node). In the AHP, it is always the bottom-up process. Specifically, criteria are pairwise compared with respect to the goal, sub-criteria with respect to the "parent" criterion, and alternatives with respect to each sub-criterion (or to the criteria, depending on the model). Pairwise comparisons are conducted for all the parent/children sets of nodes (Saaty, 2003). The use of pairwise comparisons is one of the major strengths of the AHP to derive ratio scale priorities and is more efficient than traditional approaches of assigning weights (Saaty, 2001). The input of the comparison of each element $i$ with each element $j$ is put in the position of $a_{i j}$ in a square matrix A:

$$
\mathrm{A}=\left[\begin{array}{cccc}
a_{11} & a_{12} & \ldots & a_{1 n} \\
a_{21} & a_{22} & \ldots & a_{2 n} \\
\ldots & \ldots & \ldots & \ldots \\
a_{n 1} & a_{n 2} & \ldots & a_{3 n}
\end{array}\right]
$$

Each judgment represents the dominance of an element in the column on the left over an element in the row on top. The analysis answers two questions: (1) Which of the two "children" elements is more important (preferred, likely) with respect to a "parent" element; and (2) how strong this importance/preference/likelihood is. One matrix produces "local priorities" (weighs) of the children nodes with respect to the parent. There are several methods of deriving priorities and the easiest one is to use dedicated software, such as super decisions (Saaty, 2003). Priorities can be also calculated manually with the support of a spreadsheet, using matrix multiplication, geometric mean, or arithmetic mean. The geometric mean is used quite frequently in the literature, although it was criticized as being inaccurate for more than three elements compared at once (Saaty, 2012). Mathematical background of the AHP can be found in numerous papers and books of Saaty (2000), for example. Since a majority of real-life decisions are made in the group settings, not by a stand-alone decision maker, the AHP was designed as a group-based method. Individual judgments are aggregated into the common group priorities. It can be performed in different ways, of which two being the most widely applied: (1) the aggregation of individual judgments (AIJ) and (2) synthesizing individual priorities (AIP). It has been suggested that the choice of a procedure depends on whether the group acts together as a unit or as separate individuals (Forman \& Peniwati, 1998). The AIJ is the most appropriate when the group acts in synergy, while AIP is used to aggregate final priorities of independent respondents. In the two cases, both geometric and arithmetic means are used for aggregating the results. However, geometric mean is recommended as more 
consistent with both judgments and priorities of the AHP. In the case of the group members not being of equal importance, a weighted geometric mean can be used with the AIJ or weighted geometric or arithmetic mean with the AIP (Saaty \& Peniwati, 2007).

Alongside calculating priorities, the AHP requires testing consistency of pairwise comparisons. The consistency test is based on the consistency ratio (CR), which allows a certain level of acceptable deviations $(\mathrm{CR}<0.1)$. When a pairwise comparison matrix fails to satisfy the consistency requirement, revisions have to be made by the respondents. The main source of inconsistency is the redundancy of judgments inherent in all possible combinations of pairwise comparisons made within a group of elements, for example, nine criteria require 36 judgments, and it is difficult to keep consistent such a large (and in fact redundant) number of comparisons (Prusak \& Stefanów, 2011). In case of a large number of decision alternatives, it is possible to use a 5-point Likert scale instead of pairwise comparisons (Prusak \& Stefanów, 2014). A tendency to obtain inconsistent judgments is one of the most frequently discussed disadvantages of the AHP (Alonso \& Lamata 2006; Apostolou \& Hassell, 1993; 2002). Another major weakness is a rank reversal (Millet \& Saaty, 2000; Saaty \& Sagir, 2009; Schenkerman, 1994). However, the AHP has also many advantages, including the use of hierarchical structure to represent complex problems, combining tangible and intangible elements in one model, and the possibility of using the AHP with other multi-criteria decision support methods and tools, such as DEA (Lee et al., 2011), TOPSIS (Yu, Wang, \& Gong, 2013), ELECTRE (Kaya \& Kahraman, 2011), PROMETHE (Turcksin, Bernardini, \& Macharis, 2011), and Delphi (Vidal, Marle, \& Bocquet, 2011), to name but a few examples. On top of that, the AHP can be used to solve a broad range of decision problems. There have been several attempts to review the literature concerning different AHP applications, for example, in the work of Vaidya and Kumar (2006). Over 400 examples of hierarchical models have been collected and discussed by Saaty and Forman (1992). The presented hierarchies belong to a variety of categories, including economics, business strategy, military and defense, healthcare system, and public administration. Nonetheless, there are no literature examples regarding the use of the AHP method in public administration from the client perspective, as was proposed by the authors.

\section{Research Procedure and Results}

Implementation of the AHP method in the Nowy Targ District Office was carried out according to the following procedure:

- step 1: building a group of experts;

- step 2: identifying a list of public services provided by the analyzed district based on the legal directory and strategic goals analysis;

- step 3: identifying a list of the main clients based on the list of services;

- step 4: judgment of the significance of each group of customers with respect to the district development processes;

- step 5: assessing the scale of influence of public services on each group of the customers;

- step 6: identifying public services the most important globally, from the perspective of the future policy of socioeconomic development of the district.

Step 1 implies that the research was part of a real-life decision-making process. The group of experts participating in the experiment consisted of 14 managers of high and medium level representing different departments and units of the District Office in Nowy Targ, engaged in the preparation of a new strategy of the 
district. The survey was conducted during their regular meeting. The number of participants in the similar AHP studies ranged from four (i.e., Tavana, Kennedy, Rappaport, \& Ugras, 1993) to over 30 (i.e., Meesapawong Rezgui, \& $\mathrm{Li}, 2014)$. Although the AIJ procedure was more appropriate for such a uniform group (consensus-based, AIJ using the same questionnaire for all the respondents), they preferred to complete the questionnaires individually. In this case, the separate models have been constructed and AIP procedure (aggregation of individual priorities) was applied.

In step 2, the participants were asked to verify different legal acts and strategic goals to identify public services that are obligatory (by law) or intentional (due to their importance for the strategy). As a result, a list of 22 services has been prepared (Table 1).

Table 1

The List of Services That Must or Should Be Provided by the District Office of Nowy Targ

\begin{tabular}{|c|c|}
\hline Service name & Short characteristic of the service \\
\hline $\begin{array}{l}\text { Agriculture, forestry, and } \\
\text { fishing }\end{array}$ & Veterinary support, plant protection, forestry management, and registering fishing licenses \\
\hline $\begin{array}{l}\text { Architecture (architecture and } \\
\text { construction administration) }\end{array}$ & $\begin{array}{l}\text { Assuring architectural safety and order, as well as compatibility of activities undertaken by the } \\
\text { investors with the construction law; the quality assessment of such service is based on the time } \\
\text { of decisions being issued }\end{array}$ \\
\hline Civil defense & $\begin{array}{l}\text { Maintaining military readiness of the country, at district level involving the organization of } \\
\text { crisis management and military actions (integration of emergency) }\end{array}$ \\
\hline Consumer rights protection & Protection of the consumer interests in relation with entrepreneurs \\
\hline Culture and sights & $\begin{array}{l}\text { Protection of historical monuments, development of cultural infrastructure, and organization of } \\
\text { cultural events }\end{array}$ \\
\hline Education & Ensuring education at vocational and high school level, as well as special education \\
\hline Environmental protection & $\begin{array}{l}\text { Reducing environmental pollution and waste management, issuing decisions as regards } \\
\text { environmental protection, and the use of environmental resources }\end{array}$ \\
\hline Family policy & $\begin{array}{l}\text { Providing care for low-income families, especially with many children, as well as services } \\
\text { pertaining to foster care }\end{array}$ \\
\hline Geodesy & Gathering and sharing the information regarding geodesy, cartography, and cadaster \\
\hline Healthcare & $\begin{array}{l}\text { Ensuring health services at hospitals, health promotion and prevention of diseases, particularly } \\
\text { civilization diseases }\end{array}$ \\
\hline Labor market & $\begin{array}{l}\text { Combating unemployment and activation of the unemployed (by increasing their chances for } \\
\text { employment as well as by encouraging them to start their own businesses), providing } \\
\text { unemployment benefits }\end{array}$ \\
\hline Public order and safety & Assuring public safety and crisis management against natural cataclysms or other crisis events \\
\hline $\begin{array}{l}\text { Public transport and } \\
\text { communication }\end{array}$ & $\begin{array}{l}\text { Organizing public transport, vehicle registration, and communication licenses (i.e., driving } \\
\text { licenses) }\end{array}$ \\
\hline $\begin{array}{l}\text { Real estate of central } \\
\text { administration }\end{array}$ & $\begin{array}{l}\text { Management of the central administration assets (buildings, lands, etc.) on behalf of the State } \\
\text { Treasury }\end{array}$ \\
\hline Roads (road infrastructure) & $\begin{array}{l}\text { Maintenance and development of road infrastructure in scope of local (district and municipal } \\
\text { roads) and improving road safety }\end{array}$ \\
\hline Social assistance & Providing social care for low-income people and senior citizens, including social care houses \\
\hline Sport education & Providing possibilities for physical activity and to occupy leisure time of younger people \\
\hline Support for disabled & Support for disabled, including elimination of architectural barriers and rising economic activity \\
\hline $\begin{array}{l}\text { Support of non-governmental } \\
\text { organizations }\end{array}$ & $\begin{array}{l}\text { Keeping a record of non-governmental organizations, verification of their statutory documents } \\
\text { for their compliance with law }\end{array}$ \\
\hline Telecommunication & Providing the broadband Internet, especially for people at risk of social exclusion \\
\hline Tourism & Promotion of local products, development of tourism, and tourism infrastructure \\
\hline $\begin{array}{l}\text { Water management and flood } \\
\text { protection }\end{array}$ & $\begin{array}{l}\text { Issuing licenses and permits under water rights, flood protection from development of relevant } \\
\text { infrastructure, and counteracting the flood effects }\end{array}$ \\
\hline
\end{tabular}


Subsequently, in step 3 the experts specified for whom the above services are provided. As a result, four groups of clients have been identified (Table 2).

The above list allowed creating a simple, three-level AHP model verified in step 4. The main decision goal was built around the following question: Which client (business, citizens, tourists, or central administration) should be the main focus of the socioeconomic policy of the District Office in Nowy Targ? These categories of clients constitute the criteria of the AHP model. Based on this model, the questionnaire was prepared and the study was conducted among the aforementioned experts. They were asked to assess the significance of the customers using the nine-point pairwise comparison scale. The resulting priorities are presented in Table 3.

Table 2

The List of Clients of the District Office of Nowy Targ

\begin{tabular}{|l|l|l|l|}
\hline Client name & Type of client & Short characteristic of the client & $\begin{array}{l}\text { The type of } \\
\text { relation }\end{array}$ \\
\hline Business & $\begin{array}{l}\text { Part of mobile } \\
\text { capital (potential } \\
\text { endogenic capital })\end{array}$ & $\begin{array}{l}\text { Entrepreneurs (SME's or big companies) who run their businesses in } \\
\text { the district territory, or located outside the district, but revealing } \\
\text { potential interest or willingness to move their business to the district, } \\
\text { or to open a new enterprise (unit) in the district area (particularly } \\
\text { international company) }\end{array}$ & Market-based \\
\hline Citizens & $\begin{array}{l}\text { Part of mobile } \\
\text { capital (potential } \\
\text { endogenic capital) }\end{array}$ & $\begin{array}{l}\text { Residents of the district territory or those living outside the district } \\
\text { but being potentially interested in moving to the district area and } \\
\text { being a part of local community }\end{array}$ & Market-based \\
\hline $\begin{array}{l}\text { Public } \\
\text { administration }\end{array}$ & External entities & $\begin{array}{l}\text { Public administration institutions, such as the Ministry of State } \\
\text { Treasury, who delegates certain activities to the local government, } \\
\text { particularly with respect to the management of the real estate }\end{array}$ & Regulation-based \\
\hline Tourists & External entities & $\begin{array}{l}\text { People, who are travelling (to the District of Nowy Targ), especially } \\
\text { for pleasure, usually sightseeing and using local accommodation or } \\
\text { others who are looking for an interesting place to visit }\end{array}$ & Market-based \\
\hline
\end{tabular}

Table 3

Ranking of the Clients of the District Office of Nowy Targ ${ }^{2}$

\begin{tabular}{lllll}
\hline Criteria & Mean & Max & Min & CR (mean) \\
\hline Business & w1 $=38.7 \%^{3}$ & $66.6 \%$ & $10.4 \%$ & \\
Tourists & w2 $=29.7 \%$ & $58.4 \%$ & $6.2 \%$ & CR $<0.2$ \\
Citizens & w3 $=26.1 \%$ & $42.3 \%$ & $10.6 \%$ & \\
Central administration & w4 $=5.5 \%$ & $10.0 \%$ & $3.6 \%$ & \\
\hline
\end{tabular}

Two groups of customers being very significant (business and tourists) are, in fact, those for whom it is necessary to create or redefine the existing tourism-related public services. Interestingly, those related to tourism are not obligatory public services, but are defined based on the analysis of strategic goals. In case of business, some of the existing services (i.e., roads and labor market) should be redefined, taking into account the real needs of this group of customers. Most of public services delivered by local administration are addressed mainly to citizens. Surprisingly, this group of clients has been indicated only in third place in the ranking. Furthermore, some of the services addressed mainly to citizens (ex., sport education and environmental

2 The priorities were aggregated using the AIP procedure based on the arithmetic mean of the results of 13 participants (one questionnaire was rejected due to incomplete and inconsistent data). The last column reports the average value of consistency index (CR). It indicates that most experts were rather consistent, nine respondents having $\mathrm{CR}<0.2$ (including six experts with $\mathrm{CR}$ $<0.15$, and three experts having $\mathrm{CR}<0.1$ ).

3 Aggregated priorities of the clients. 
protection) have been identified by the experts as factors influencing more tourists than citizens. This situation requires changes in processes of providing and financing of these services. They should be redefined and optimized taking into account the significance of the clients.

During the next round (step 5) the experts evaluated public services with respect to each group of clients. They answered the following question: What is the significance of a public service with respect to business, tourists, citizens, and central administration (taking into account the specific needs of each client)? In this step, a simplified procedure was used to assess the services. The number of elements was too high for the AHP pairwise analysis, as it would give 231 combinations of pairs and result in extremely high inconsistency. Thus, participants were asked to assign values from 1 (negligible influence) to 5 (very strong influence) of the public services for each group of clients. Such simplification is recommended, if it is impossible to reduce a large number of decision alternatives (Prusak \& Stefanów, 2014). Using the nine-point scale would be impossible for 22 variants, as the maximum number of the elements being compared at once should not exceed nine (Miller, 1956).

The results of this analysis are summarized in Figure 3 below. It provides information on the public services with respect to each group of clients. Due to the size restrictions of the paper, it is limited to the services with grades 4.0 and higher.

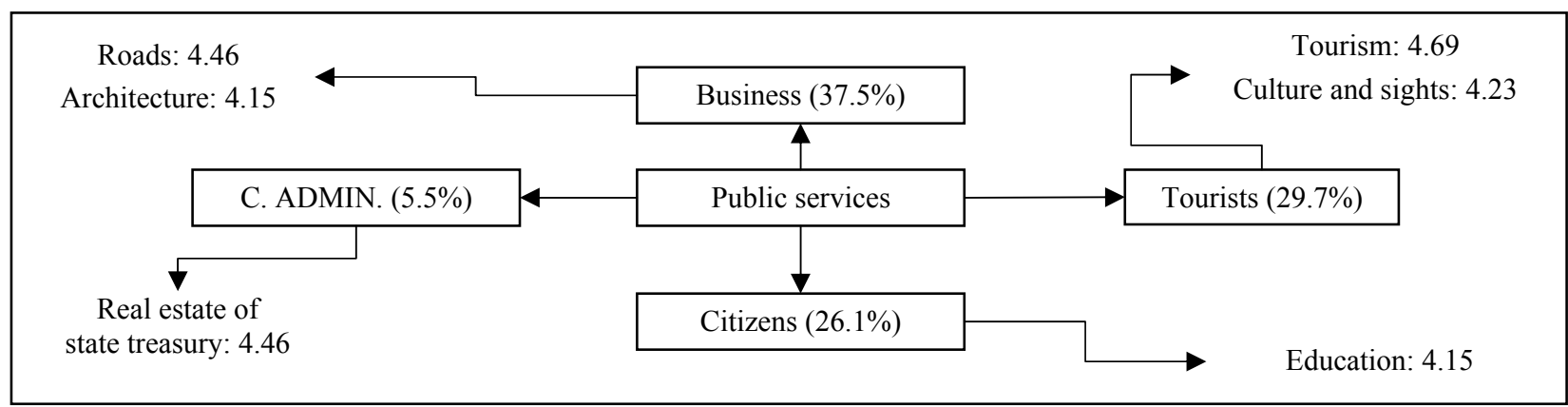

Figure 3. Public services with the highest influence on the perceived satisfaction of clients of the District Office of Nowy Targ.

For the clients of business category, the key services are roads, architecture, and labor market. Development of road infrastructure and keeping public roads in good condition are in fact the main tasks of the district. High quality roads are key in running a variety of business activities. It is of particular importance in mountainous regions with high tourist potential. The reported district is part of such region. As regards another key service - architecture, the district should develop administrative procedures facilitating investment operations. An important factor in running any business is the labor market. In this respect, the appropriate mechanisms should be developed to match labor supply with demand generated by enterprises.

In case of tourists, four key public services have been defined. First of them, tourism, is about defining the appropriate tourism development policy of the district. It is not the obligatory task of local authorities and as such, not included in legal directory. However, due to specific tourist attractions and the strategic goals of the district, this service is of crucial importance. It should be supported by other public services addressed to this group, such as culture and sights, roads, and public transport, which may further improve the attractiveness of the region.

Public services of particular importance for citizens are education, public transport, and roads. These services are used by inhabitants on a regular basis and therefore directly influence the quality of life. Secondary 
level education is one of the most difficult and expensive tasks of the district. Educational programs should be correlated with local labor market and correspond with the requirements of higher education. Public transport and roads determine safety and comfort of movement within the district. There are two explanations of why these services are weighted as very important. Firstly, the district is located in mountain area, where the requirements regarding the quality of the roads are very high due mainly to the difficult weather conditions prevailing for most of the year. Secondly, the district struggles with the seasonal flow of traffic, increased further during the weekends, due to the intensive movement of tourists.

As regards central administration, the service pertaining to real estate of central administration is about the real estate management (buildings and plots), such as, control of their use and the process of sale. This public service brings significant income for the district.

Table 4

Ranking of the Clients of the District Office of Nowy Targ ${ }^{4}$

\begin{tabular}{|c|c|c|c|c|c|c|c|c|c|}
\hline \multirow{2}{*}{ Criteria } & \multicolumn{2}{|c|}{$\begin{array}{c}\text { Business }\left(\mathrm{w}_{1}=\right. \\
38.7 \%)\end{array}$} & \multicolumn{2}{|c|}{$\begin{array}{c}\text { Tourists }\left(\mathrm{w}_{2}=\right. \\
29.7 \%)\end{array}$} & \multicolumn{2}{|c|}{ Citizens $\left(\mathrm{w}_{3}=26.1\right)$} & \multicolumn{2}{|c|}{$\begin{array}{c}\text { State Treasury } \\
\left(\mathrm{w}_{4}=0.054\right)\end{array}$} & \multirow{2}{*}{$\begin{array}{l}\text { Sum of } \\
\text {-global } \\
\text { values }\end{array}$} \\
\hline & Mean & $\begin{array}{l}\text { Global } \\
\text { value }\end{array}$ & Mean & $\begin{array}{l}\text { Global } \\
\text { value }\end{array}$ & Mean & $\begin{array}{l}\text { Global } \\
\text { value }\end{array}$ & Mean & $\begin{array}{l}\text { Global } \\
\text { value }\end{array}$ & \\
\hline Roads & 4.15 & 1.61 & 4.08 & 1.21 & 4.46 & 1.16 & 3.31 & 0.18 & 4.16 \\
\hline Public transport and comm. & 4.15 & 1.61 & 4.15 & 1.23 & 3.62 & 0.94 & 2.62 & 0.14 & 3.93 \\
\hline Tourism & 4.69 & 1.82 & 3.23 & 0.96 & 3.62 & 0.94 & 2.15 & 0.12 & 3.84 \\
\hline Sport education & 3.77 & 1.46 & 3.31 & 0.98 & 3.00 & 0.78 & 2.46 & 0.14 & 3.36 \\
\hline Environmental protection & 3.69 & 1.43 & 3.23 & 0.96 & 2.92 & 0.76 & 3.31 & 0.18 & 3.33 \\
\hline Culture and sights & 4.23 & 1.64 & 2.92 & 0.87 & 2.54 & 0.66 & 2.85 & 0.16 & 3.32 \\
\hline Telecommunication & 3.15 & 1.22 & 3.31 & 0.98 & 3.54 & 0.92 & 2.08 & 0.11 & 3.24 \\
\hline Architecture & 2.23 & 0.86 & 3.54 & 1.05 & 4.15 & 1.08 & 3.31 & 0.18 & 3.18 \\
\hline Public order and safety & 3.38 & 1.31 & 3.15 & 0.94 & 2.92 & 0.76 & 3.08 & 0.17 & 3.18 \\
\hline Education & 2.38 & 0.92 & 4.15 & 1.23 & 3.15 & 0.82 & 2.69 & 0.15 & 3.12 \\
\hline Labor market & 1.54 & 0.60 & 3.85 & 1.14 & 4.00 & 1.04 & 3.00 & 0.17 & 2.95 \\
\hline Healthcare & 2.38 & 0.92 & 3.54 & 1.05 & 2.85 & 0.74 & 3.00 & 0.17 & 2.88 \\
\hline Water management and ... & 2.62 & 1.01 & 2.69 & 0.80 & 2.85 & 0.74 & 3.38 & 0.19 & 2.74 \\
\hline Support for disabled & 2.15 & 0.83 & 2.92 & 0.87 & 2.54 & 0.66 & 2.85 & 0.16 & 2.52 \\
\hline Agriculture & 2.46 & 0.95 & 2.77 & 0.82 & 2.15 & 0.56 & 2.62 & 0.14 & 2.48 \\
\hline Geodesy & 1.38 & 0.53 & 2.69 & 0.80 & 3.38 & 0.88 & 3.46 & 0.19 & 2.41 \\
\hline Family policy & 1.77 & 0.68 & 3.23 & 0.96 & 2.23 & 0.58 & 2.38 & 0.13 & 2.36 \\
\hline Consumer rights protection & 2.31 & 0.89 & 2.77 & 0.82 & 1.77 & 0.46 & 2.15 & 0.12 & 2.30 \\
\hline Real estate of State Treasury & 1.23 & 0.48 & 2.15 & 0.64 & 3.15 & 0.82 & 4.46 & 0.25 & 2.18 \\
\hline Social assistance & 1.23 & 0.48 & 2.92 & 0.87 & 2.31 & 0.60 & 2.92 & 0.16 & 2.11 \\
\hline Support of non-gov. org. & 1.62 & 0.63 & 2.46 & 0.73 & 2.08 & 0.54 & 2.38 & 0.13 & 2.03 \\
\hline Civil defense & 1.15 & 0.45 & 2.00 & 0.59 & 1.85 & 0.48 & 3.15 & 0.17 & 1.70 \\
\hline
\end{tabular}

In step 6, the results of the previous steps have been synthesized in order to determine which of the 22 public services are the most important in general (globally) taking into account all groups of clients and their importance (Table 4). To obtain this information, the aggregated priorities of the clients (w1, w2, w3, and w4)

\footnotetext{
${ }^{4}$ The priorities were aggregated using the AIP (Aggregating Individual Priorities) procedure based on the arithmetic mean of the results of 13 participants (one questionnaire was rejected due to incomplete and inconsistent data). The last column reports the average value of Consistency Index (CR). It indicates that most experts were rather consistent, nine respondents having $\mathrm{CR}<0.2$ (including six experts with $\mathrm{CR}<0.15$ and three experts having $\mathrm{CR}<0.1$ ).
} 
calculated in step 4 were multiplied by the mean value of the influence of public services on the perceived satisfaction of these clients, evaluated at the five-point scale. The final scores indicate which public services are the most significant for the policy of socioeconomic development realized by the District Office of Nowy Targ.

The most important public service is roads. Other public services of high importance include public transport, tourism, sport education, environmental protection, culture, and sights. All these services correspond to the specific (mountain) character of the region and determine its tourist attractiveness. Notably, tourists are strongly related to business customers, as the development of tourism is of fundamental importance for the local economy and provides budget revenues that enable the local authorities to optimize the quality of public services. The district strategy also assumes that income from tourism should provide a target level of the citizens' wealth.

\section{Conclusions}

The paper presents one of the first attempts to implement the AHP method in a real-life decision-making, strategic management process in public administration in Poland. The results of the analysis were used in the document Socioeconomic Development Strategy of the Nowy Targ district for the years 2015-2022. It is one of the few examples of adopting the customer-centered approach to development of such strategic document by local authorities in Poland. Thus, the study should be perceived as an innovative case with application potential in this area in Poland.

The ranking of the importance of public services with respect to particular groups of clients (Figure 3) as well as globally (Table 4) may be used as suggestion for future development policies (strategic level) and customer satisfaction surveys (operational level). These also allow drawing conclusions as regards potential changes in the existing organizational structure of the District Office, for example, employment and delegation of responsibilities should be proportional to the relevant importance of public services. However, the latter suggestion is difficult to implement in practice. Polish legislation adopted the formula, which imposes regional and local administration to specific tasks, not problems to be solved. Subsequently, legal directories provide the rigid list of services, alongside with the source of their funding. It hinders freedom, and thus also more effective and efficient resource allocation, tailored to the identified strategic needs, for example, tourism is one of the public services that can be funded mainly from the district own resources or from external sources (i.e., EU funds), but there is a small amount of money from central government. The similar situation is in the case of other services. Therefore, local authorities should secure additional funding, if they want to change the way of providing services, optimizing this process to the individual priorities.

To sum up the study, several methodological conclusions should be drawn. The AHP method applied in the reported case study is in an advanced stage of its life cycle. Numerous examples of the AHP use and very sophisticated examples of implementation and suggestions for the AHP research procedures are widely described in the world literature. Thus, the present paper did not intend to produce an additional value from methodological point of view. However, there were identified and formulated certain postulates as regards application potential and further implementation of the AHP in public administration in Poland. They have more general character and are valid for other sectors, too. These are as follows:

One of the major challenges and key aspects of the procedure of the AHP application in practice is the identification and selection of experts, as well as the method of conducting the survey. In the reported study, 
group meetings of managers of high and medium level were used.

The four categories of clients used in the analysis (business, citizens, tourists, and central administration) may be too generic. It would be useful to divide these groups into further subcategories, i.e., business including big companies and SME's. It will allow being more focused on the specific needs of the customers and addressing the public services more efficiently. The authors will consider it in the subsequent studies.

The implementation of any method to the management practice requires consideration from the perspective of its complexity and time. In general, people do not like complex and time-consuming analyses, which do not create value added to the efficiency of the existing processes. Consequently, these are not implemented or their results are useless. From this perspective, the procedure demonstrated in the present research seems to be optimal with respect to the complexity and time.

The authors wish to thank the authorities of the District Office of Nowy Targ for their openness and willingness to implement new solutions, which may contribute to the increased efficiency and effectiveness of public management. At the same time, it creates a new know-how in the area of public management, providing empirical implications in the use of various systems, structures, methods, and techniques.

\section{References}

Alonso, A., \& Lamata, T. (2006). Consistency in the analytic hierarchy process-A new approach. International Journal of Uncertainty, Fuzziness and Knowledge-Based Systems, 14(4), 445-459.

Apostolou, B., \& Hassell, J. M. (1993). An empirical examination of the sensitivity of the analytic hierarchy process to departures from recommended consistency ratios. Mathematical and Computer Modeling, 17(4-5), 163-170.

Apostolou, B., \& Hassell, J. M. (2002). Note on consistency ratio: A reply. Mathematical and Computer Modelling, 35(9-10), 1081-1083.

Bobińska, B. (2012). Funkcjonowanie sektora publicznego jako organizacji otwartych na klienta. Zeszyty Naukowe Zachodniopomorskiej Szkoły Biznesu, Firma i Rynek, 1(66), 59-71.

Boex, J. (2012). Exploring the measurement and effectiveness of the local public sector: Toward a classification of local public sector finances and a comparison of devolved and deconcentrated finances. Retrieved from http://www.urban.org/research/publication/exploringmeasurement-and-effectiveness-local-public-sector

Bouckaert, B. (1995). Remodeling quality and quantity in a management context. In A. Halachmi and G. Bouckaert (Eds.), Public productivity through quality and strategic management (pp. 21-38). Amsterdam: IOS Press.

Buchacz, T., \& Wysocki, S. (2002). Zarządzanie jakością w administracji-Europejskie wzorce, polskie doświadczenia. Stużba Cywilna, 5, 29-56.

Bury, P., \& Swianiewicz, P. (2008). Local government finance in Poland. In Z. Sevic (Ed.), Local public finance in Central and Eastern Europe (pp. 319-341). Cheltenham: Edward Eglar Publishing.

Charbonneau, É., \& Van Ryzin, G. G. (2012). Performance measures and parental satisfaction with New York City schools. The American Review of Public Administration, 42(1), 54-65.

Forman, E., \& Peniwati, K. (1998). Aggregating individual judgments and priorities with the analytic hierarchy process. European Journal of Operational Research, 108(1), 165-169.

Fornell, C., Johnson, M. D., Anderson, E. W., \& Cha Jeasung, B. E. (1996). The American customer satisfaction index: Nature, purpose, and findings. The Journal of Marketing, 60, 7-18.

Graham, J., Amos, B., \& Plumptre, T. (2003). Principles for good governance in the 21st century. Policy Brief, 15, 1-6.

Kaya, T., \& Kahraman, C. (2011). An integrated fuzzy AHP-ELECTRE methodology for environmental impact assessment. Expert Systems With Applications, 38(7), 8553-8562.

Kelly, J. M. (2005). The dilemma of the unsatisfied customer in a market model of public administration. Public Administration Review, 65(1), 76-84.

Kersting, N., \& Vetter, A. (2013). Reforming local government in Europe: Closing the gap between democracy and efficiency. Opladen: Leske+Budrich. 
Lee, S. K., Mogi, G., Li, Z., Hui, K. S., Lee, S. K., Hui, K. N., \& Kim, J. W. (2011). Measuring the relative efficiency of hydrogen energy technologies for implementing the hydrogen economy: An integrated fuzzy AHP/DEA approach. International Journal of Hydrogen Energy, 36(20), 12655-12663.

Meesapawong, P., Rezgui, Y., \& Li, H. (2014). Planning innovation orientation in public research and development organizations: Using a combined Delphi and analytic hierarchy process approach. Technological Forecasting and Social Change, 87, 245-256.

Miller, G. A. (1956). The magical number seven, plus or minus two: Some limits on our capacity for processing information. The Psychological Review, 63, 81-97.

Millet, I., \& Saaty, T. L. (2000). On the relativity of relative measures-Accommodating both rank preservation and rank reversals in the AHP. European Journal of Operational Research, 121(1), 205-212.

Moore, N., Clarke, R., Johnson, S., Seargeant, J., \& Steele, J. (1998). People and public services: A review of research into people's expectations and experiences of public services. London: The Office for Public Management and Acumen.

Osborne, S. P., Radnor, Z., \& Nasi, G. (2013). A new theory for public service management? Toward a (public) service-dominant approach. The American Review of Public Administration, 43(2), 135-158.

Parliament. (1990). Municipal government act. Warsaw, Poland: Parliament.

Parliament. (1998a). District government act. Warsaw, Poland: Parliament.

Parliament. (1998b). Regional government act. Warsaw, Poland: Parliament.

Prusak, A., \& Stefanów, P. (2011). Badania nad właściwościami operacyjnymi metody AHP. Folia Oeconomica Cracoviensia, 52, 87-104.

Prusak, A., \& Stefanów, P. (2014). AHP_Analityczny proces hierarchiczny. Warszawa: CH Beck.

Rhys, A., \& Van de Walle, S. (2013). New public management and citizens' perceptions of local service efficiency, responsiveness, equity and effectiveness. Public Management Review, 15(5), 762-783.

Saaty, R. W. (2003). Decision making in complex environments. The analytic hierarchy process (AHP) for decision making and the analytic network process (ANP) for decision making with dependence and feedback. Pittsburgh: Creative Decisions Foundation.

Saaty, T. L. (2000). Fundamentals of decision making and priority theory with the analytic hierarchy process (2nd ed.). Pittsburgh: RWS Publications.

Saaty, T. L. (2001). Decision making with dependence and feedback: The analytic network process. Pittsburgh: RWS Publications.

Saaty, T. L. (2008). Relative measurement and its generalization in decision making. Why pairwise comparisons are central in mathematics for the measurement of intangible factors the analytic hierarchy/network process. RACSAM (Revista de La Real Academia de Ciencias Exactes, Fisicas Y Naturales. Serie A. Matematicas), 102(2), 251-318.

Saaty, T. L. (2012). Decision making for leaders. Pittsburgh: RWS Publications.

Saaty, T. L., \& Forman, E. H. (1992). The hierarchon: A dictionary of hierarchies (1st ed.). Pittsburgh: RWS Publications.

Saaty, T. L., \& Peniwati, K. (2007). Group decision making: Drawing out and reconciling differences (1st ed.). Pittsburgh: RWS Publications.

Saaty, T. L., \& Sagir, M. (2009). An essay on rank preservation and reversal. Mathematical and Computer Modeling, 49(5-6), $1230-1243$.

Schenkerman, S. (1994). Avoiding rank reversal in AHP decision-support models. European Journal of Operational Research, 74(3), 407-419.

Schmidt, F., \& Strickland, T. (1998). Client satisfaction surveying: Common measurements tool. Ottawa: Canadian Centre for Management Development.

Sołtys, J. (2013). Usługi publiczne jako czynnik miastotwórczy i wyznacznik rangi miasta w sieci osadniczej na przykładzie małych miast Polski północnej. Acta Universitatis Lodziensis, Folia Geographica Socio-Oeconomica, 15, 3-19.

Soma, K., \& Vatn, A. (2014). Representing the common goods-Stakeholders vs. citizens. Land Use Policy, 41, 325-333.

Tavana, M., Kennedy, D. T., Rappaport, J., \& Ugras, Y. J. (1993). An AHP-Delphi group decision support system applied to conflict resolution in hiring decisions. Journal of Management Systems, 5(1), 49-74.

Turcksin, L., Bernardini, A., \& Macharis, C. (2011). A combined AHP-PROMETHEE approach for selecting the most appropriate policy scenario to stimulate a clean vehicle fleet. Procedia-Social and Behavioral Sciences, 20, 954-965. 
Vaidya, O. S., \& Kumar, S. (2006). Analytic hierarchy process: An overview of applications. European Journal of Operational Research, 169(1), 1-29.

Vidal, L. A., Marle, F., \& Bocquet, J. C. (2011). Using a Delphi process and the analytic hierarchy process (AHP) to evaluate the complexity of projects. Expert Systems With Applications, 38(5), 5388-5405.

Weiss, T. G. (2000). Governance, good governance and global governance: Conceptual and actual challenges. Third World Quarterly, 21(5), 795-814.

Yu, J., Wang, L., \& Gong, X. (2013). Study on the status evaluation of urban road intersections traffic congestion base on AHP-TOPSIS modal. Procedia-Social and Behavioral Sciences, 96, 609-616. 